\begin{tabular}{|c|c|c|c|}
\hline \multirow{3}{*}{$\begin{array}{r}\text { Case Reports in } \\
\text { Gastroenterology }\end{array}$} & \multirow{2}{*}{\multicolumn{2}{|c|}{ Case Rep Gastroenterol 2020;14:34-38 }} & \multirow[b]{3}{*}{$\begin{array}{l}\text { Karger } \\
\text { Opengaccess }\end{array}$} \\
\hline & & & \\
\hline & $\begin{array}{l}\text { DOI: } 10.1159 / 000505510 \\
\text { Published online: January 20, } 2020\end{array}$ & $\begin{array}{l}\text { (c) } 2020 \text { The Author(s) } \\
\text { Published by S. Karger AG, Basel } \\
\text { www.karger.com/crg }\end{array}$ & \\
\hline & $\begin{array}{l}\text { This article is licensed under the } \\
\text { International License (CC BY-NC) } \\
\text { Usage and distribution for commerc }\end{array}$ & $\begin{array}{l}\text { mons Attribution-NonCommercial } 4.0 \\
\text { rger.com/Services/OpenAccessLicense). } \\
\text { quires written permission. }\end{array}$ & \\
\hline
\end{tabular}

\title{
Endoscopic Treatment of Solitary Colonic Ganglioneuroma
}

\author{
Toshio Arai ${ }^{a}$ Hiroki Yamada ${ }^{a}$ Takeya Edagawa ${ }^{a}$ Satoshi Yoshida ${ }^{a}$ \\ Shunji Maekura ${ }^{\mathrm{b}}$ Kenichiro Nakachi ${ }^{\mathrm{a}}$ \\ aDepartment of Gastroenterology, Hashimoto Municipal Hospital, Hashimoto, Japan; \\ ${ }^{b}$ Department of Pathology, Hashimoto Municipal Hospital, Hashimoto, Japan
}

\section{Keywords}

Ganglioneuroma $\cdot$ Colonoscopy $\cdot$ Fecal occult blood test

\begin{abstract}
Ganglioneuromas (GNs) in adults are uncommon clinical entities, especially in the colon. Patients with GNs without multiple endocrine neoplasia or neurofibromatosis-I are normally asymptomatic; however, GNs can present with abdominal pain, weight loss, bleeding, and anemia, depending on the size and location. Here, we present a case of solitary colonic GN treated with endoscopic mucosal resection. A 40-year-old Japanese outpatient with a positive fecal occult blood test visited our hospital. We performed diagnostic colonoscopy, which revealed a polyp of $15-\mathrm{mm}$ diameter in the ascending colon. Electromagnetic resonance imaging was performed, and the histological examination revealed benign polypoid spindle-cell proliferation, ganglion cells, and thick nerve bundles, which was positive for S-100 protein immunoreactivity consistent with GN.

(C) 2020 The Author(s) Published by S. Karger AG, Basel
\end{abstract}

\section{Introduction}

Ganglioneuromas (GNs) are benign tumors derived from the sympathetic ganglia and adrenal glands, and they occur more commonly in children than in adults [1]. Although these tumors are most frequently found in the abdomen, they can also reside at any location occupied by the sympathetic nervous system. GNs of the intestinal tract are rare and categorized 


\section{Case Reports in Gastroenterology}

Case Rep Gastroenterol 2020;14:34-38

DOI: $10.1159 / 000505510$

c) 2020 The Author(s). Published by S. Karger AG, Basel www.karger.com/crg

Arai et al.: Endoscopic Treatment of Solitary Colonic Ganglioneuroma

into three groups: isolated polyp (polypoid), multiple polyps (ganglioneuromatous polyposis) and diffuse ganglioneuromatosis [2,3]. Patients are typically asymptomatic, and the GNs are found incidentally on colonoscopic screening $[1,4]$. In this report, we present a case of solitary colonic GN discovered during a colonoscopy. Due to a lack of guidelines on solitary colonic GNs, we discuss our treatment approach and review the literature relevant to this rare case.

\section{Case Report}

A 40-year-old Japanese man with a positive fecal occult blood test underwent a colonoscopy for colon cancer screening. He had no significant personal or family medical history nor any abdominal symptoms. His vital signs were normal, and physical examination revealed normal bowel sounds, with no tenderness or palpable masses in the abdomen. Laboratory tests of peripheral blood revealed hemoglobin level of $12.5 \mathrm{~g} / \mathrm{dL}$, hematocrit level of $38.0 \%$, MCV of $89.2 \mathrm{fL}$, a platelet count of $278,000 / \mu \mathrm{L}$, and white blood cell count of $4,200 / \mu \mathrm{L}$.

We used a PCF-H290Zl endoscope (Olympus Medical System, Tokyo, Japan) to perform a diagnostic colonoscopy. The diagnostic colonoscopy by conventional white light observation (enhancement mode-A7) revealed a solitary flat elevated polyp in the ascending colon. The polyp was approximately $15 \mathrm{~mm}$ in diameter with an irregular shape and with a mixed reddish colored mucosa. Most of its surface was smooth, but a portion contained a cloud-like lesion (Fig. 1a). Using non-magnified narrow-band image (NBI) observation (enhancement mode B8), we observed that the vessels and surface pattern were consistent with Narrowband imaging International Colorectal Endoscopic (NICE) classification Type 1 [5] (Fig. 1b). We used magnified NBI and the Japan NBI Expert Team classification to determine that the polyp was consistent with Type 1 (Fig. 1c) [6]. Because this finding was consistent with a sessile serrated adenoma/polyp or hyperplastic polyp, we performed a diagnostic endoscopic mucosal resection, with no complications.

Hematoxylin and eosin staining revealed spindle cells and ganglion cells in thick nerve bundles (Fig. 2a). Follow-up staining for S-100 proteins and (Fig. 2b) synaptophysin (Fig. 2c) yielded positive results. Negative controls were obtained by omitting the antibodies to S-100 proteins (Fig. 2d). These findings were consistent with GNs. After the histological diagnosis, the patient underwent thyroid ultrasonography, enhanced abdominal computed tomography, and upper gastrointestinal endoscopy to rule out the possibility of systemic disease, including neurofibromatosis 1 and multiple endocrine $2 \mathrm{~B}$ syndrome. The results were all negative; hence, the final diagnosis was colonic solitary GN.

\section{Discussion}

GNs of the gastrointestinal tract are rare, benign hamartomatous tumors consisting of ganglion cells, nerve fibers, and supporting cells of the enteric nervous system.

There might be no association between solitary GNs and cancer, but studies have reported that intestinal GNs can cause bleeding and bowel obstruction, depending on their size and location $[1,4,7]$. Therefore, solitary GNs might need treatment, but no guidelines or specific treatment recommendations are available. However, similar to other cases reported in the literature that were also successfully treated with polypectomy $[1,4,8,9]$, the GN in our case was located on the lamina propria in the colon. Thus, we assume that endoscopic resection can be a curative method for solitary GNs. 
There is no evidence regarding the effectiveness of surveillance colonoscopy. Ofori et al. [1] state that frequent repeat colonoscopies as follow-up might not be necessary, while Crystal reported a recurrent case of solitary GN in the colon [10]. Thus, the optimal interval for repeat colonoscopies is controversial. Solitary GNs are benign tumors not associated with the subsequent development of neurofibromatosis-I or multiple endocrine neoplasia [11]. Overall, the prognosis is good. The patient in our study is doing well 10 months after the treatment; thus, a repeat colonoscopy will not be scheduled.

In summary, we presented a case of an adult patient with a colonic solitary GN. Our report, along with recent similar reports, suggests that endoscopic treatment can be curative. However, future studies are required to confirm the efficacy of this approach.

\section{Acknowledgment}

We thank the staff at Department of Pathology, Hashimoto Municipal Hospital. We also thank Dr. Yoko Kato, Heart and Vascular Institute, Johns Hopkins University for reviewing this case report.

\section{Statement of Ethics}

No ethical approval was obtained because this study did not involve a prospective evaluation, did not involve laboratory animals, and the data collected are confidential. We received written consent from the patient.

\section{Disclosure Statement}

The authors declare that there is no conflict of interest regarding the publication of this paper.

\section{Funding Sources}

There were no funding sources.

\section{Author Contributions}

Toshio Arai wrote this paper, and all other authors equally contributed to the patient's medical treatment and diagnosis.

\section{References}

1 Ofori E, Ona M, Ramai D, Huang T, Xiao P, Reddy M. Colonic ganglioneuroma: A rare finding during colorectal cancer screening. Case Rep Gastroenterol. 2017 Aug;11(2):434-9.

2 Fernandes A, Ferreira AM, Serra P, Carvalho L. Intestinal ganglioneuromatosis: an unusual aetiology for occult gastrointestinal bleeding. BMJ Case Rep. 2015 Sep;2015:1-5. 
3 Kim TJ, Lim H, Kang HS, Moon SH, Kim JH, Park CK, et al. Diffuse ganglioneuromatosis of the colon presenting as a large subepithelial tumor in adults: report of two cases. Korean J Gastroenterol. 2015 Aug;66(2):111-5.

4 Fiori E, Pozzessere C, Lamazza A, Leone G, Borrini F, Schillaci A, et al. Endoscopic treatment of ganglioneuroma of the colon associated with a lipoma: a case report. J Med Case Rep. 2012 Sep;6(1):304.

5 Hewett DG, Kaltenbach T, Sano Y, Tanaka S, Saunders BP, Ponchon T, et al. Validation of a simple classification system for endoscopic diagnosis of small colorectal polyps using narrow-band imaging. Gastroenterology. 2012 Sep;143(3):599-607.e1.

6 Komeda Y, Kashida H, Sakurai T, Asakuma Y, Tribonias G, Nagai T, et al. Magnifying Narrow Band Imaging (NBI) for the diagnosis of localized colorectal lesions using the Japan NBI Expert Team (JNET) Classification. Oncology. 2017;93(1 Suppl 1):49-54.

7 Carter JE, Laurini JA. Isolated intestinal neurofibromatous proliferations in the absence of associated systemic syndromes. World J Gastroenterol. 2008 Nov;14(42):6569-71.

8 Abraham G, Prakash SR. Solitary colonic ganglioneuroma: A rare incidental finding of Hematochezia. Case Rep Gastrointest Med. 2015;2015:794985.

9 Alkhatib AA, Tamara C. Isolated colonic polypoid ganglioneuroma. J Am Osteopath Assoc. 2013 May;113(5):433.

10 Crystal RF. Colonic ganglioneuroma. Arch Surg. 1980 May;115(5):676.

11 Shekitka KM, Sobin LH. Ganglioneuromas of the gastrointestinal tract. Relation to Von Recklinghausen disease and other multiple tumor syndromes. Am J Surg Pathol. 1994 Mar;18(3):250-7.
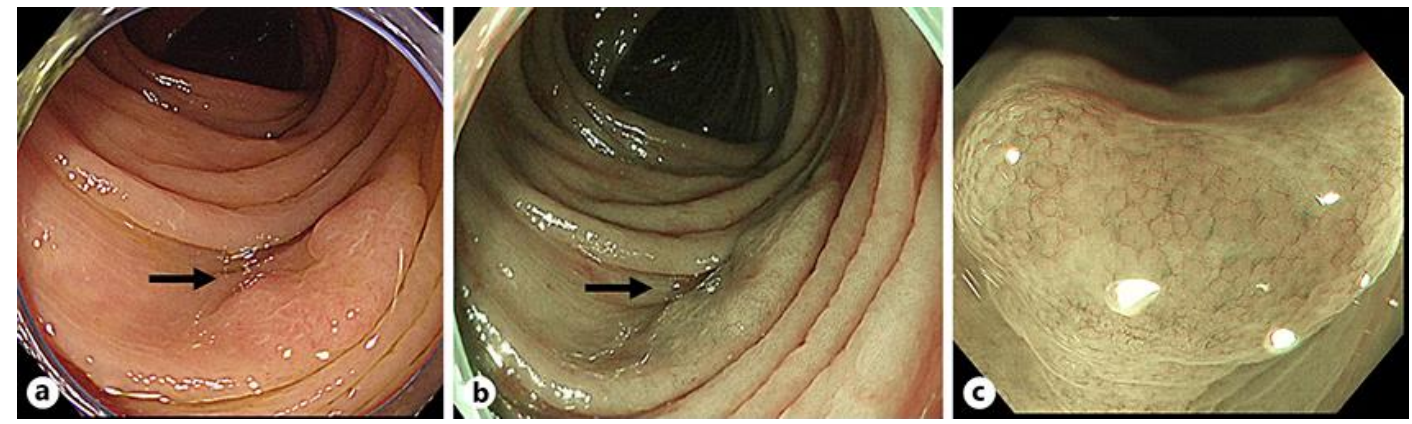

Fig. 1. Endoscopic image of the solitary ganglioneuroma. a Endoscopic image with white light shows the polyp of $15 \mathrm{~mm}$ in diameter covered with reddish colored mucosa (arrow) in the ascending colon. $\mathbf{b}$ Endoscopic image with narrow-band imaging (NBI) reveals the light-dark color similar to the background, cloud-like surface, distinct border, irregular shape, and no visible vessels (arrow). c Endoscopic image with NBI followed by magnification represents no visible vessel and similar surrounding normal mucosa. 


\section{Case Reports in Gastroenterology}
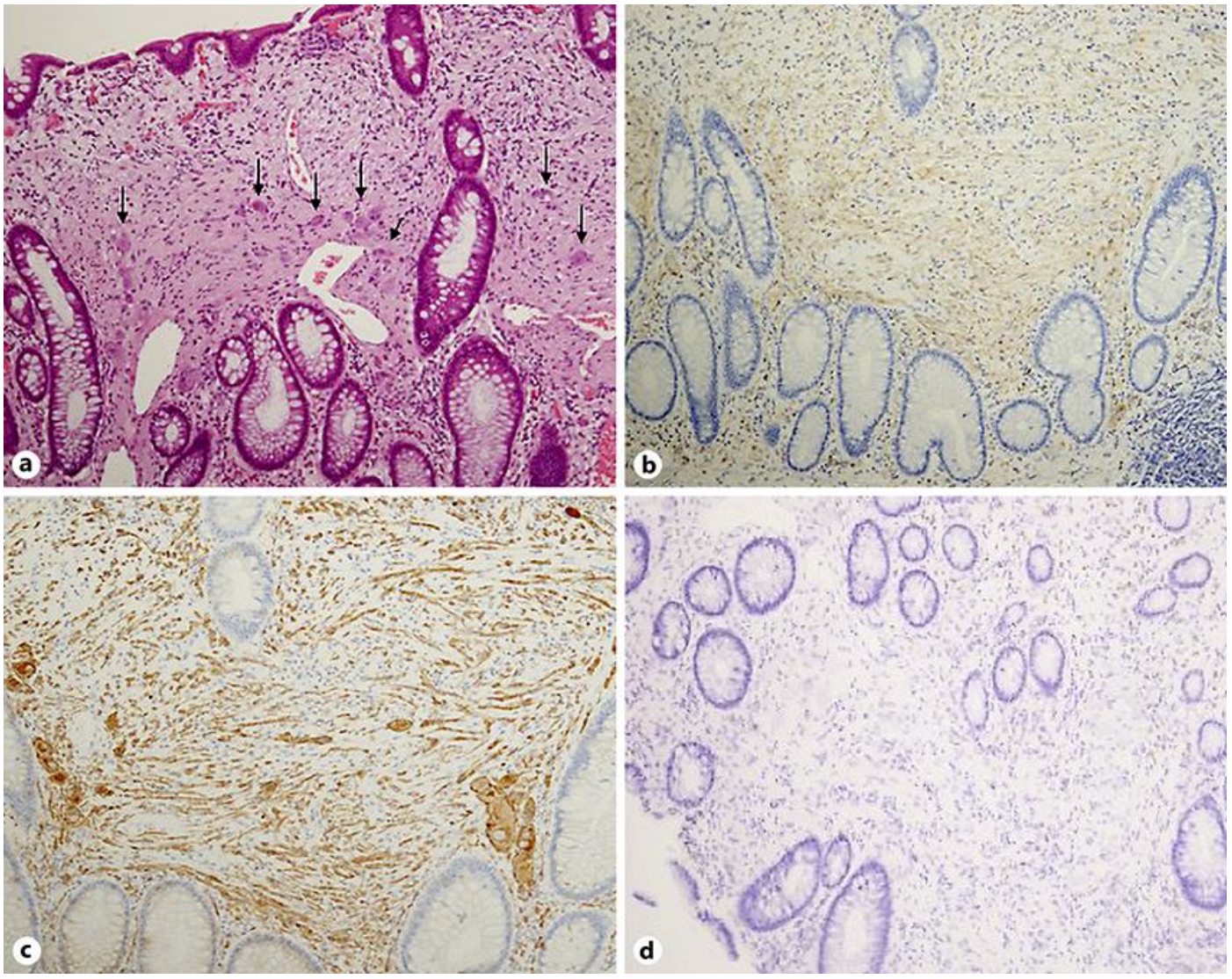

Fig. 2. Histological examination of the ganglioneuroma. a Hematoxylin and eosin stain shows ganglion cells (arrows) in the lamina propria. Magnification, $\times 10$. b Immunohistochemical stain demonstrates S100 immunoreactivity. Magnification, $\times 10$. c Immunohistochemical stain demonstrates synaptophysin immunoreactivity. Magnification, $\times 10$. $\mathbf{d}$ Negative control staining for the immunohistochemistry. Magnification, $\times 10$. 